\title{
SEMI-HYDROPONIC CULTIVATION AS A SELECTION TOOL FOR ALUMINUM TOLERANCE IN FORAGE GRASSES
}

Gustavo André Colombo ${ }^{1}$, Aurélio Vaz de $\mathrm{Melo}^{2}$, Gilberto Coutinho Machado Filho ${ }^{3}$, André Silva de Sousa ${ }^{4}$

\begin{abstract}
The constant improvement of selection methods is necessary in order to optimize efficiency of breeding programs for aluminum tolerance. Thus, the aim of this study was to establish a vase volume to the ideal semi-hydroponic cultivation of forage grasses subjected to stress by aluminum in nutrient solution. The experimental design completely randomized, with four replicates, each replicate consisting of one plant per vase. The treatments were arranged in a factorial design 4x5, being the first factor consists of four genotypes of forage grasses Brachiaria Humidicola; Brachiaria brizantha cv. Piatã; Panicum maximum cv. Massai and Panicum maximum cv. Mombaça) and the second consisting of five separate volumes plastics vases where seedlings were grown $\left(0.2 ; 0.25 ; 0.3 ; 0.35\right.$ and $\left.0.4 \mathrm{dm}^{3}\right)$. The grasses grown in a semi-hydroponics system irrigated with nutrient solution rich in aluminum $\left(3 \mathrm{mg} \mathrm{L}^{-1}\right)$. Was measured plant height, dry weight of aereal part and root length. The semi-hydroponic cultivation in aluminum increased nutrient solution is effective in differentiation of forage grasses genotypes in relation to aluminum tolerance. Pots volumes near $0.3 \mathrm{dm}^{3}$ promote greater development for root and aerial part attributes in forage grasses grown in nutrient solution with aluminum toxicity.
\end{abstract}

Keywords: toxic aluminum, abiotic stress, nutrient solution, forage production

\section{RESUMO}

\section{CULTIVO SEMI-HIDROPÔNICO COMO FERRAMENTA DE SELEÇÃO PARA TOLERÂNCIA AO ALUMÍNIO EM GRAMÍNEAS FORRAGEIRAS}

O aprimoramento constante das ferramentas de seleção se faz necessário, no sentido de otimizar a eficiência de um programa de melhoramento para tolerância ao alumínio. Desta forma, o objetivo deste trabalho foi estabelecer um volume de vaso ideal ao cultivo semi-hidropônico de gramíneas forrageiras submetidas ao estresse por alumínio em solução nutritiva. O delineamento experimental utilizado foi o inteiramente casualizado, com quatro repetições, sendo cada repetição constituída por uma planta por vaso. Os tratamentos foram dispostos em esquema fatorial $4 \times 5$, sendo o primeiro fator constituído por quatro genótipos de gramíneas forrageiras (Brachiaria Humidicola; Brachiaria brizantha cv. Piatã; Panicum maximum cv. Massai e Panicum maximum cv. Mombaça) e o segundo constituído de cinco volumes distintos de vasos plásticos onde as plântulas foram cultivadas $\left(0,2 ; 0,25 ; 0,3 ; 0,35\right.$ e $\left.0,4 \mathrm{dm}^{3}\right)$. As plântulas foram cultivadas em sistema semi-hidropônico com solução nutritiva rica em alumínio $\left(3 \mathrm{mg} \mathrm{L}^{-1}\right)$. Foram mensuradas a altura de plantas, massa seca da parte aérea e comprimento de raiz. O cultivo semi-hidropônico foi eficaz na diferenciação de genótipos de gramíneas forrageiras em relação à tolerância ao alumínio. Volumes de vasos próximos a $0,3 \mathrm{dm}^{3}$ favoreceram o desenvolvimento dos atributos do sistema radicular e da parte aérea em gramíneas forrageiras cultivadas em solução nutritiva com a toxidez de alumínio.

Palavras-chave: Alumínio tóxico, estresse abiótico, solução nutritiva, produção de forragem

\section{Recebido para publicação em 04/01/2016. Aprovado em 25/08/2016.}

1 - Engenheiro Agrônomo, Doutorando em Produção Vegetal/UFT, Gurupi-TO, colombo@uft.edu.br

2 - Engenheiro Agrônomo, Doutor em Fitotecnia, Professor/UFT, Gurupi-TO, vazdemelo@uft.edu.br

3 - Acadêmico de Agronomia, UFT/campus de Gurupi, Gurupi-TO, coutinhoagro@hotmail.com

4 - Acadêmico de Agronomia, UFT/campus de Gurupi, Gurupi-TO, andresousa0@hotmail.com

\section{REVENG}

350-356p. ENGENHARIA NA AGRICULTURA, VIÇOSA - MG, V.24 N.4, JULHO / AGOSTO 2016 


\section{INTRODUCTION}

In Brazil, the beef cattle production is characterized by farming systems that use grasslands, providing $99 \%$ of the diet for cattle herds. The pastures managed in extensive system, with low use of fertilizers or, in most cases, without the addition of these inputs, so that the productivity levels of livestock systems are low, and over time production, declines are evident (DIAS-FILHO, 2011).

New areas opening for cattle pasture is getting more restrict, and gradually limited to marginal areas with low fertile soil and high acidity, rich in aluminum and other toxic elements (MACEDO, 2009). Aluminum is toxic to most species of cultivated plants by promoting the inhibition of root growth and, consequently, hindering the development of plants (CANÇADO et al., 2001). Thus, the operation of these pasture land need, increasingly, the selection of forage that is adapted to those conditions (EUCLIDES, 2000).

Character aluminum tolerance in forage species has received attention from breeding programs (OLIVEIRA et al., 2013; BITENCOURT et al., 2011; MATINS et al., 2011). According to Ryan et al. (1993), the $\mathrm{Al}^{3+}$ is present predominantly in the root area of the plant, and the apexes of the roots its critical site of toxicity. Thus, methods that measure restricting root growth receive more attention as a parameter in the evaluation of $\mathrm{Al}^{3+}$ toxicity (CRESTANI et al., 2011; CRESTANI et al., 2009; VOSS et al., 2006; MAZZOCATO et al., 2002).

Reviews in field conditions have traditionally been used in the plant tolerance study about $\mathrm{Al}^{3+}$ toxic, by depicting more faithfully the natural growing conditions (MISTRO et al., 2001; CAMARGO et al., 1995; FERREIRA et al., 1986). However, most interference from external factors of hard control in this type of study priority the cultivation in nutrient solution to facilitate the work by environment control and ease visualization of $\mathrm{Al}^{3+}$ effect on interested attribute (LANA et al., 2013; MACEDO et al., 2011; REIS et al., 2009). Crestani et al. (2009) signalize that growing in nutrient solution also allows evaluating large number of genotypes in short period of time in the early stages of plant development, providing significant improvements to the efficiency of selection.

Different methods based on cultivation in nutrient solutions have been developed in evaluation of tolerance and sensitivity to $\mathrm{Al}^{3+}$ in annual and perennial species. Cardoso et al. (2004) proposed semi-hydroponics method in nutrient solution in which the species of interest is transplanted, still in seedling stage for a polyethylene vase containing an inert substrate, suspended over a container containing nutrient solution. In this way, contact with the substrate allows plant root system realize gas exchange, while the rest of the roots are immersed in the nutritive solution prepared for each study. For toxicity studies $\mathrm{Al}^{3+}$, Furlani and Hanna (1984) showed nutrient solution composed of a series of chemical elements essential for plant associated with the nce of aluminum - potassium decahydrate $\left(\mathrm{AlK}\left(\mathrm{SO}_{4}\right)_{2} \cdot 12 \mathrm{H}_{2} \mathrm{O}\right)$ as element source.

However, in all hydroponics system, priority should be given a homogeneous distribution of root system on the nutrient solution. Whereas the availability of nutrients to plants is also affected by morphological and physiological attributes of each plant species (SCHENK and BARBER, 1979), attributes such as length, volume and surface roots must be considered in experimental design. Moreover, plant roots have a high demand for oxygen by the high respiration rate (MARSCHNER, 1995), provide the necessary aeration system becomes essential to plant development in full growth medium.

The constant improvement of methodologies is necessary in order to optimize the evaluation process efficiency and selection of genotypes tolerant to aluminum. Thereby, the aim of this study was to establish the ideal vase volume semihydroponic cultivation of forage grasses subjected to stress by aluminum in nutrient solution.

\section{MATERIALS AND METHODS}

The experiment was conducted in greenhouse at the Experimental Station of the Federal University of Tocantins, Campus of Gurupi, at coordinates $11^{\circ} 43^{\prime} 45^{\prime \prime}$ latitude and $49^{\circ} 04^{\prime} 07^{\prime \prime}$ longitude. The experimental design completely randomized, with four replicates, each replicate consisting of one plant per vase. 
The treatments were arranged in a factorial 4 $\mathrm{x} 5$, the first factor consists of four genotypes of forage grasses (Brachiaria humidicola; Brachiaria brizantha cv. Piatã; Panicum maximum cv. Massai and Panicum maximum cv. Mombaça) and the second consisting of five different volumes of plastic pots where seedlings were grown $(0.2 ; 0.25$; $0.3 ; 0.35$ and $0.4 \mathrm{dm}^{3}$ ).

The seeds of the genotypes germinated on filter paper, spaced from each other in one centimeter. The paper was rolled up and moistened with distilled water. These rolls were placed in germination chamber at $25^{\circ} \mathrm{C}$, as described by Brasil (1992). After 60 hours, the rollers were removed and the germinating plants were selected for uniformity. Subsequently, these plantlets were placed individually in plastic vases.

In cultivation of seedlings of grasses used the double vase methodology adapted from Cardoso et al. (2004), where cylindrical plastic pots of $75 \mathrm{dm}$ diameter containing washed sand, were superimposed with the aid of a support, a polyethylene tray measuring $45 \mathrm{~cm}$ long, $30 \mathrm{~cm}$ wide and $12.0 \mathrm{~cm}$ deep, containing nutrient solution (Figure 1). In shared double vases (20 plots per tray) of the roots grown in liquid medium and solid medium part as a way to avoid the necessity of artificial aeration of the solution.

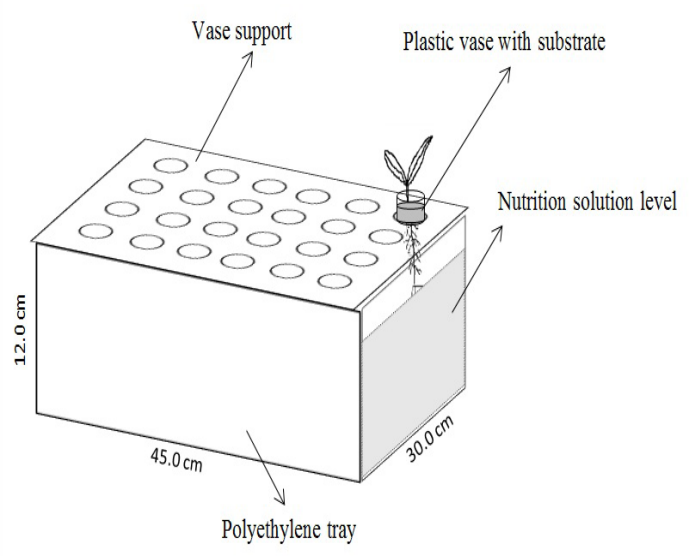

Figure 1. Illustration of double vase shared, adapted from Cardoso et al. (2004).

Seedlings received daily irrigation with nutrient solution similar to that defined by Furlani and Hanna (1984), however, with a 50\% reduction in the concentration of calcium. The aluminum stress was simulated by adding to the nutritive solution at a single concentration of $3 \mathrm{mg} \mathrm{L}^{-1}$, in the form of aluminum - potassium decahydrate $\left(\mathrm{AlK}\left(\mathrm{SO}_{4}\right)_{2} \cdot 12 \mathrm{H}_{2} \mathrm{O}\right)$.

After 25 days elapsed germination, the plants were picked, separate the shoot roots, and evaluated the plant height $(\mathrm{PH})$, measured in centimeters from the ground base to the apex of the larger sheet; and the root length $(\mathrm{RL})$, measured in centimeters from the insertion base end to the main root.

Subsequently they were identified accommodated in paper bags and placed in a forced ventilation oven at a temperature of $60^{\circ} \mathrm{C}$ for 72 hours. After this period, the material was weighed to determine the dry weight of the aerial part (DWAP).

The data were submitted to regression analysis, assessing the significance of the betas and the coefficients of determination using the statistical program SigmaPlot 11.0 software (SIGMAPLOT, 2008).

\section{RESULTS AND DISCUSSION}

All genotypes showed quadratic response depending to the increase in the volume of growing vases. The determination coefficients were significant $(p<0.05)$ in all genotypes. The same occurred in both regression coefficients $\left(\beta^{-1}\right.$ and $\beta^{-2}$ ). The increase in the vases caused a significant effect on the root length (RL) of cultivated grasses (Figure 2).

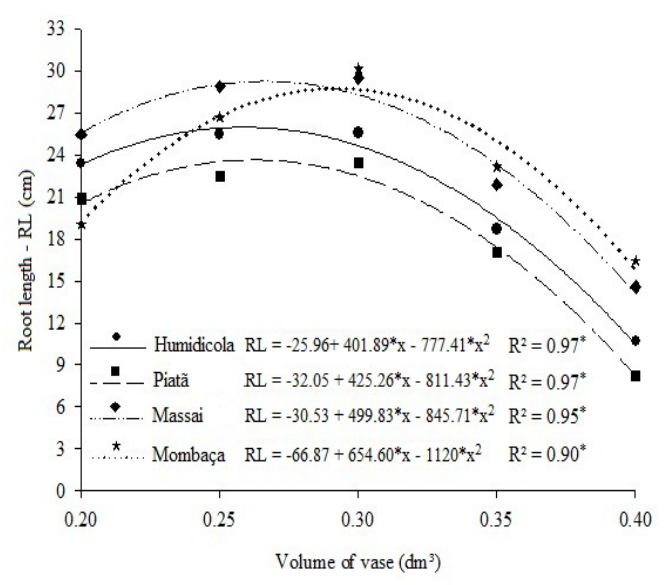

Figure 2. Root length of forage grasses genotypes depending on the volume of vases for semi-hydroponic cultivation in nutrient solution, 25 days after germination, Gurupi-TO 2015. 
By observing the maximum response point in $\mathrm{RL}$ of the four genotypes, it appears that there are differences in vase volume ideal for the full root development. Grasses B. humidicola, Piatã and Massai had similar maximum points $(0.258 ; 0.262$ and $0.266 \mathrm{dm}^{3}$, respectively), while Mombaça grass was more demanding in volume vase, reaching maximum response point RL with vases of 0.292 $\mathrm{dm}^{3}$.

The four grass species decreased in the RL when grown in vases $0.2 \mathrm{dm}^{3}$. This behavior can have occurred by the fact that this volume vase has not accommodated a sufficient root portion to find the respiration rate of the root system. Low availability of oxygen to roots can be because small volume of substrate available for the roots, it undertook the process of gas exchange by root metabolism. With lack of oxygen, oxidative phosphorylation is blocked and metabolism starts work anaerobically, severely affecting plant growth (SAIRAM et al., 2008).

Similar reduction in RL occurred in the four genotypes grown in pots of $0.35 \mathrm{dm}^{3}$ and 0.4 $\mathrm{dm}^{3}$. However, when subjected to higher volumes vase, the root system shows growth and space exploration laterally, less inducement to deepen roots, resulting in delay of contact with the nutrient solution. Since most of the absorbent root hairs do not exploit the nutrient solution, with an expected frame nutritional failure and consequent decrease in plant growth. According to Barber (1995), the plants tend to uncontrolled emission of roots, as a mechanism to increase efficiency in the interception of nutrients. Prado et al. (2011), evaluating seedlings Panicum maximum cv. Tanzânia in nutrient solution, observed reductions of up to $87 \%$ in root length, due to weak absorption of macronutrients.

As for plant height (PH), all genotypes showed quadratic response due to the increase in the volume of growing vases. The determination coefficients were significant $(p<0.05)$ in all genotypes. The same observed in both regression coefficients (Figure 3).

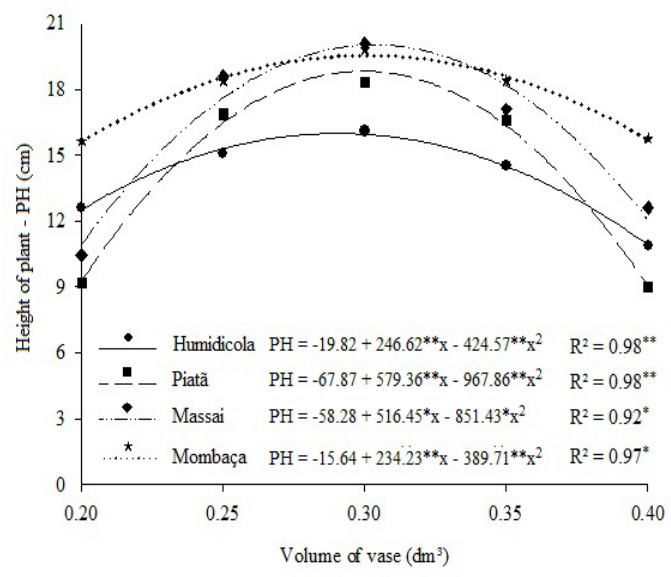

Figure 3. Height of plant genotypes of forage grasses depending on the volume of vases to semi-hydroponic cultivation in nutrient solution, 25 days after germination, Gurupi-TO 2015.

It showed shorter variation in the volume of vases that provided maximum increase in $\mathrm{PH}(4.48 \%$ difference between the four genotypes) compared to the volumes observed for RL. The genotypes $B$. humidicola, Piatã, Massai and Mombaça have peak in $\mathrm{PH}$ with potted $0.290 ; 0.299 ; 0.303$ and 0.301 $\mathrm{dm}^{3}$, respectively.

The results observed in $\mathrm{PH}$ are reflections of root development of genotypes. In the $0.2 \mathrm{dm}^{3}$ vases, the shoot elongation was compromised by the low metabolic rate, as a result of hypoxia that the root system was subjected. Studies show that lack of oxygen in the soil is able to significantly reduce the photosynthetic capacity in non-tolerant grasses (CAETANO and DIAS-FILHO, 2008; SOUSA and SODEK, 2002). Ramos et al. (2011), by evaluating physiological and metabolic changes B. Brizantha plants subjected to conditions of root hypoxia, observed a significant reduction in photo synthetic rate, due to stomatal imbalances when compared to plants under normal conditions.

About the dry weight of the aerial part (DWAP), all genotypes showed quadratic response due to the increase in the volume of growing vases. The determination coefficients were significant $(p<0.05)$ in all genotypes. The same observed in both regression coefficients (Figure 4). 


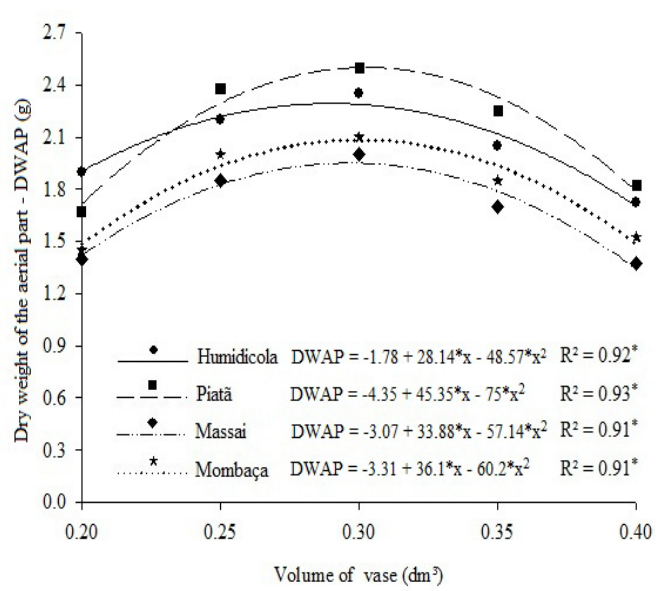

Figure 4. Dry weight of the aerial part of forage grasses genotypes depending on the volume of vases to semi-hydroponic cultivation in nutrient solution, 25 days after germination, Gurupi-TO 2015.

The grasses $B$. humidicola, Piatã, Massai and Mombaça show maximum increment of points similar DWAP $\left(0.289 ; 0.302 ; 0.296\right.$ and $0.299 \mathrm{dm}^{3}$, respectively), with change of $4.5 \%$ between them.

Overall, the genotypes grown in pots of 0.2 $\mathrm{dm}^{3}$ compromise the results presented at the three characteristics studied. This presents insufficient dimension to accommodate a substrate portion that allows the plant to perform the process of breathing and gas exchange medium by full root tissue, not supplying the breathing demand of the plant. Deficit in the biochemical phase of photosynthesis, providing energy for cell metabolism is precarious, and results in lower $\mathrm{PH}$ and DWAP, directly correlated to energy supply (TAIZ and ZEIGER, 2009).

When grown in vases $0.35 \mathrm{dm}^{3}$ and $0.4 \mathrm{dm}^{3}$, genotypes found aggravating for its vegetative growth, a decrease in all attributes, indicating that these volumes are too big for semi-hydroponic cultivation. In that condition, the initial root portion is located exclusively in the substrate layer with reduced exposure of roots to nutrient solution, damaging essential nutrients absorption for metabolism. According to Tavares et al. (2012), in an experiment with genre grasses Cynodon and Digitaria, the layer of $0-10 \mathrm{~cm}$ responsible for about $70 \%$ of the mass and number of roots, responsible for $49 \%$ of absorption and accumulation of nutrients in shoot.

Despite the four species have presented different responses depending on the vase volume used in semi-hydroponic cultivation, it can say that volumes close to $0.3 \mathrm{dm}^{3}$ promoted greater development for the studied attributes. However, it is important to alert that for each genotype, there is an ideal volume for better measurement of stressful effect on the plant, and it is up to the researcher to carry out prior determination of the ideal vase volume according to the genotype studied. In addition to satisfying reliability and experiment significance, the use of vases with smaller volumes can have real gains, with economy vases substrate and physical space, and temporal gains, with the agility to obtaining results.

For situations of stress for aluminum, where all treatments are equally exposed to stressful situation, the use of vases with ideal volume gives real answers of the effect of toxic aluminum in the metabolism of genotypes, excluding external factors that can distort the observations and macular selection tolerant individuals.

\section{CONCLUSIONS}

- The semi-hydroponic cultivation in aluminum increased nutrient solution is effective in differentiation of forage grasses genotypes in relation to aluminum tolerance.

- Vase volumes near $0.3 \mathrm{dm}^{3}$ promote greater development for root and aerial part attributes in forage grasses grown in nutrient solution with aluminum toxicity.

\section{BIBLIOGRAPHICS REFERENCES}

BARBER, S.A. Soil nutrient bioavailability: a mechanistic approach. 2.ed. New York, John Wiley \& Sons, 1995.

BITENCOURT, G.D.A.; CHIARI, L.; LAURA, V.A.; VALLE, C.B.D.; JANK, L.; MORO, J.R. Aluminum tolerance on genotypes of signal grass. Revista Brasileira de Zootecnia, Viçosa, v.40, n.2, p.245-250, 2011.

BRASIL, Ministério da Agricultura e Reforma 
Agrária. Regras para análise de sementes. Brasília: SNDA/DNDV/ CLV, 1992. 365p.

CAETANO, L.P.S.; DIAS-FILHO, B.M. Responses of six Brachiaria spp. accessions to root zone flooding. Revista Brasileira de Zootecnia, v.37, n.5, 2008.

CAMARGO, C.E.D.O.; FELÍCIO, J.C.; FERREIRA FILHO, A.W.P.; FREITAS, J.G.D.; RAMOS, V.J.; KANTHACK, R.A.D.; CASTRO, J.L.D. Melhoramento do trigo: XXX. Avaliação de linhagens com tolerância à toxicidade de alumínio, manganês e ferro em condições de campo. Bragantia, Campinas, v.54, n.1, p.81-93, 1995.

CANÇADO, G.M.A.; CARNEIRO, N.P.; CARNEIRO, A.A.; PURCINO, A.A.C.; GUIMARÃES, C.T.; ALVES, V.M.C.; PARENTONI, S.N.; SOUZA, I.R.P.; PAIVA, E. Novas perspectivas para adaptação de culturas ao Cerrado: pesquisa contribuição da biologia molecular na compreensão e solução dos efeitos tóxicos do alumínio em plantas. Biotecnologia Ciência \& Desenvolvimento, Brasília, v.4, n.23, p.56-61, 2001.

CARDOSO, I.M.; BODDINGTON, C.L.; JANSSEN, B.H.; OENEMA, O.; KUYPER, T.W. Double pot and double compartment: Integrating two approaches to study nutrient uptake by arbuscular mycorrhizal fungi. Plant and Soil, Dordrecht, v.260, p.301-310, 2004.

CRESTANI, M.; CARVALHO, F.I.F.; OLIVEIRA, C.O.; SILVA, J.A.G.; SOUZA, V.Q.; PARACHU, E.A.M.; SILVEIRA, G.; RIBEIRO, G.E.; LUCHE, H.S. Estresse por alumínio em genótipos de aveia preta em condição hidropônica. Bragantia, Campinas, v.68, n.3, p.639-649, 2009.

CRESTANI, M.; SILVA, J.A.G.D.; TESSMANN, E.W.; SILVEIRA, S.F.D.S.; NORNBERG, R.; RIBEIRO, G.; OLIVEIRA, A.C.D. Protocolos para seleção quanto à tolerância ao alumínio em aveia sob cultivo hidropônico. Current Agricultural Science and Technology, Pelotas, v.17, n.3, p.311320, 2011.
DIAS-FILHO, M.B. Degradação de pastagens: processos, causas e estratégias de recuperação. 3.ed. Belém: Embrapa Amazônia Oriental, 2007. 190p.

EUCLIDES, V.P.B. Alternativas para intensificação da produção de carne bovina em pastagem. Campo Grande: Embrapa Gado de Corte, 65p. 2000.

FERREIRA, R.P.; SALGADO, L.T.; JORGE, H.D. Tolerância de cultivares de arroz ao alumínio. Pesquisa Agropecuária Brasileira, Brasília, v. 21, n. 12, p. 1257-1260, 1986.

FURLANI, P.R.; HANNA, L.G. Avaliação da tolerância de plantas de arroz e milho ao alumínio em solução nutritiva. Revista Brasileira de Ciência do Solo, v.8, n.2, p.205-208, 1984.

LANA, M.C.; STEINER, F.; ZOZ, T.; FEY, R.; FRANDOLOSO, J. F. Tolerance of physic nut plants to aluminum activity in nutrient solution. Bioscience Journal, Uberlândia, v.29, n.3, p.582-589, 2013.

MACEDO, M.C.M. Integração lavoura e pecuária: o estado da arte e inovações tecnológicas. Revista Brasileira de Zootecnia, Viçosa, v.38, p.133-146, 2009.

MACEDO, F. L.; PEDRA, W. N.; DA SILVA S. A.; VASCONCELLOS BARRETO, M. C.; SILVA-MANN, R. Efeito do alumínio em plantas de pinhão-manso (Jatropha curcas L.), cultivadas em solução nutritiva. Semina: Ciências Agrárias, Londrina, v.32, n.1, p.157-164, 2011.

MARSCHNER, H. Mineral nutrition of higher plants. 2.ed. London: Academic Press, 1995. 889p.

MATINS, C.E.; MIGUEL, P.S.B.; ROCHA, W.S.D.D.; SOBRINHO, F.S.; GOMES, F.T.; OLIVEIRA, A.V.D. Seleção de genótipos de Brachiaria Ruziziensis quanto à tolerância ao alumínio em solução nutritiva: I: Resposta a diferentes concentrações de alumínio e valores de ph em solução nutritiva. Revista de Ciências Agrárias, Belém, v.34, n.1, p.154-162, 2011. 
MAZZOCATO, A.C.; ROCHA, P.S.G.; SERENO, M.J.C.M.; BOHNEN, H.; GRONGO, V.; BARBOSA NETO, J.F. Tolerância ao alumínio em plântulas de milho. Ciência Rural, Santa Maria, v.32, p.19-24, 2002.

MISTRO, J.C.; CAMARGO, C.E.D.O.; PETTINELLI-JÚNIOR, A. Avaliação de genótipos de trigo, de diferentes origens, em relação à toxicidade de alumínio. Bragantia, Campinas, v.60, n.3, p.177-184, 2001.

PRADO, R.M.; HOJO, R.H.; AVALHÃES, C.C.; VALE, D.W.; PIMENTEL, U.V. Desempenho do capim-tanzânia cultivado em solução nutritiva com à omissão de macronutrientes. Scientia Agraria Paranaenis, v.10, n.1, p.58-68, 2011.

OLIVEIRA, K.M.B.; CHIARI, L.; BARRIOS, S.C.L.; LAURA, V.A. Avaliação de Híbridos Intraespecíficos de Brachiaria decumbens Stapf (Poaceae) para Tolerância ao Alumínio. In: I WORKSHOP SOBRE TOLERÂNCIA A ESTRESSES ABIÓTICOS, 2013, Campo Grande. Anais... Campo Grande: Embrapa Gado de Corte, 2013. p.15-25.

RAMOS, T.J.N.; SOUZA, C.M.A.; CARVALHO, C.J.R.; VIEIRA, I.M.S. Respostas fisiológicas e metabólicas de gramíneas ao alagamento. Revista de Ciências Agrárias, Belém, v.54, p.78-84, 2011.

REIS, C.E.; DA SILVA, J.A.; CARVALHO, F.I.; OLIVEIRA, A.C.D.; MARTINS, J.L.; FINATTO, T.; CRESTANI, M. Caracterização de cultivares de aveia quanto a tolerância à toxicidade ao alumínio avaliadas em hidroponia. Current Agricultural Science and Technology, Pelotas, v.15, n.1-4, p.57-64, 2009.
RYAN, P.R.; DITOMASE, J.M.; KOCHIAN, L.V. Aluminum toxicity in roots: an investigation of spatial sensitivity and the role of the root cap. Journal of Experimental Botany, Lancaster, v.44, p.437-446, 1993.

SAIRAM, R.K.; KUMUTHA, D.; EZHILMATHI, K.; DESHMUKH, P.S.; SRIVASTAVA, G.C. Physiology and biochemistry of waterlogging tolerance in plants. Biologia Plantarum, Prague, v.52, n.3, p.401-412, 2008.

SCHENK, M.K.; BARBER, S.A. Phosphate uptake by corn as affected by soil characteristics and root morphology. Soil Science Society of America Journal, Madison, v.43, p.880-883, 1979.

SIGMAPLOT. Statistics for user's guide, Chicago, Systat Software Inc, 2008. 578p.

SOUSA, C.A.F.; SODEK, L. Respostas metabólicas de plantas a deficiência de oxigênio. Brazilian Journal of Plant Physiology, v.14, p.83-94, 2002.

TAIZ, L.; ZEIGER, E. Fisiologia vegetal. 4. ed. Porto Alegre: Artmed, 2009. 722p.

TAVARES, C.A.; PEREIRA, G.O.; CAMARGO FILHO, S.T. Altura do dossel como parâmetro para estimativa da disponibilidade de massa seca de três capins estoloníferos no período seco. Cadernos de Agroecologia, Cruz Alta, v.7, p.4-14, 2012.

VOSS, M.; SOUSA, C.D.; BAIER, A.C., NASCIMENTO JÚNIOR, A.; BOFF, T. Método de avaliação de tolerância à toxidez de alumínio em trigo, em condições de hidroponia, na Embrapa Trigo. Passo Fundo, RS: Embrapa Trigo, 2006. 16p. 